\title{
HIF1a is a direct regulator of steroidogenesis in the adrenal gland
}

\author{
Deepika Watts $^{1} \cdot$ Johanna Stein $^{1} \cdot$ Ana Meneses ${ }^{1} \cdot$ Nicole Bechmann $^{1,2,3} \cdot$ Ales Neuwirth $^{1} \cdot$ Denise Kaden $^{1}$. \\ Anja Krüger ${ }^{1}$. Anupam Sinha ${ }^{1}$ - Vasileia Ismini Alexaki ${ }^{1}$. Luis Gustavo Perez-Rivas ${ }^{4}$ - Stefan Kircher ${ }^{5}$. \\ Antoine Martinez ${ }^{6} \cdot$ Marily Theodoropoulou $^{4} \cdot$ Graeme Eisenhofer $^{1} \cdot$ Mirko Peitzsch $^{1} \cdot$ Ali El-Armouche ${ }^{7}$. \\ Triantafyllos Chavakis ${ }^{1} \cdot$ Ben Wielockx ${ }^{1}$ (B)
}

Received: 15 September 2020 / Revised: 17 December 2020 / Accepted: 23 December 2020 / Published online: 19 January 2021 (c) The Author(s) 2021

\begin{abstract}
Endogenous steroid hormones, especially glucocorticoids and mineralocorticoids, derive from the adrenal cortex, and drastic or sustained changes in their circulatory levels affect multiple organ systems. Although hypoxia signaling in steroidogenesis has been suggested, knowledge on the true impact of the HIFs (Hypoxia-Inducible Factors) in the adrenocortical cells of vertebrates is scant. By creating a unique set of transgenic mouse lines, we reveal a prominent role for HIF1 $\alpha$ in the synthesis of virtually all steroids in vivo. Specifically, mice deficient in HIF1 $\alpha$ in adrenocortical cells displayed enhanced levels of enzymes responsible for steroidogenesis and a cognate increase in circulatory steroid levels. These changes resulted in cytokine alterations and changes in the profile of circulatory mature hematopoietic cells. Conversely, HIF $1 \alpha$ overexpression resulted in the opposite phenotype of insufficient steroid production due to impaired transcription of necessary enzymes. Based on these results, we propose HIF $1 \alpha$ to be a vital regulator of steroidogenesis as its modulation in adrenocortical cells dramatically impacts hormone synthesis with systemic consequences. In addition, these mice can have potential clinical significances as they may serve as essential tools to understand the pathophysiology of hormone modulations in a number of diseases associated with metabolic syndrome, auto-immunity or even cancer.
\end{abstract}

Keywords Hypoxia-inducible factor · Adrenocortical steroids · Oxygen sensors · Cytokines

\section{Introduction}

Steroidogenesis in the adrenal gland is a complex process of sequential enzymatic reactions that convert cholesterol into steroids, including mineralocorticoids and glucocorticoids

Supplementary Information The online version contains supplementary material available at https://doi.org/10.1007/s0001 8-020-03750-1.

\section{Ben Wielockx}

Ben.Wielockx@tu-dresden.de

1 Institute of Clinical Chemistry and Laboratory Medicine, Technische Universität Dresden, Fetscherstrasse 74, 01307 Dresden, Germany

2 Department of Experimental Diabetology, German Institute of Human Nutrition Potsdam-Rehbruecke, 14558 Nuthetal, Germany

3 German Center for Diabetes Research (DZD), 85764 München-Neuherberg, Germany

4 Medizinische Klinik Und Poliklinik IV, Ludwig-Maximilians-Universität (LMU) München, Munich, Germany [1]. While glucocorticoids are regulated by the hypothalamic-pituitary-adrenal axis (HPA axis) and are essential

5 Institute of Pathology, University Würzburg, Würzburg, Germany

6 Génétique Reproduction and Dévelopement (GReD), Centre National de la Recherche Scientifique (CNRS), INSERM, Université Clermont-Auvergne, Clermont-Ferrand, France

7 Department of Pharmacology and Toxicology, Medical Faculty, Technische Universität Dresden, 01307 Dresden, Germany 
for stress management and immune regulation [2, 3], aldosterone, the primary mineralocorticoid, regulates the balance of water and electrolytes in the body [4]. As steroidogenesis is a tightly regulated process, proper control of adrenal cortex function relies on appropriate endocrine signaling, tissue integrity, and homeostasis [5]. Accordingly, it has been suggested that inappropriately low $\mathrm{pO}_{2}$, or hypoxia, can lead to both structural changes in the adrenal cortex and interfere with hormone production [6-10].

Hypoxia-inducible factors (HIFs) are the main transcription factors that are central to cellular adaptation to hypoxia in virtually all cells of our body. The machinery that directly controls HIF activity consists of the HIF-prolyl hydroxylase domain-containing enzymes (PHD-1, -2, -3) (encoded by the Egln-2, -1, -3 genes, respectively), which are oxygen sensors that hydroxylate two prolyl residues in the HIF $\alpha$ subunit under normoxic conditions, thereby marking the HIFs for proteasomal degradation. Conversely, oxygen insufficiency renders these PHDs inactive, leading to the binding of the HIF-complex to hypoxia-responsive elements (HRE) in the promoter of multiple genes that ensure oxygen delivery and promote adaptive responses to hypoxia such as hematopoiesis, blood pressure regulation, and energy metabolism (reviewed in [11, 12]). Apart from directly activating hypoxia-responsive genes [13, 14], HIFs also indirectly influence gene expression by interfering with the activity of other transcription factors or systems. Of the most intensively studied HIF $\alpha$ genes, HIF $1 \alpha$ has a ubiquitous pattern of expression in all tissues, whereas expression of the paralogue HIF $2 \alpha$ is restricted to a selection of cell types including endothelial cells, liver hepatocytes, epithelial cells of the intestinal lumen, glia cells in the brain and renal erythropoietin-producing cells [15-18].

Recent in vitro and zebrafish studies have revealed a continuous crosstalk between HIF and steroidogenesis pathways, along with potential interference in the production of aldosterone and glucocorticoids [19-22]. Most hypoxiarelated findings on steroidogenesis come from granulosa cells, either showing a direct role for HIF $1 \alpha$ in regulating Star, the mitochondrial cholesterol transporter [20, 23], or suggesting an inverse role on steroidogenesis [24]. In the adrenocortical carcinoma cell line H295R, hypoxia resulted in downregulation of steroidogenic genes, while downregulation of CYP19A1 was regulated by HIF1 via induction of miR-98 [25]. There is also evidence suggesting a role for the hypoxia pathway in modulating glucocorticoid/glucocorticoid receptor (GR) signaling [26, 27]. Importantly, these observations indicate a possible interplay of HIFs and PHDs in modulating the immune-regulatory actions of the HPA axis. Currently, there is huge interest in the development of HIF inhibitors and HIF stabilizers, and their influence on medicine is expected to become significant in the near future [28]. However, as the role of HIFs/PHDs is both central and manifold with respect to maintaining oxygen homeostasis, a better understanding of the true impact of Hypoxia Pathway Proteins (HPPs) in the complex interplay of different essential physiological and pathological conditions, including in the adrenal cortex, assumes great importance.

We describe the creation of a unique collection of transgenic mouse lines that enables an investigation of the role of HIF $\alpha$ subunits in adrenocortical cells and beyond. Our results point towards a central role for HIF1 $\alpha$ in the direct regulation of steroidogenesis in the adrenal gland and consequent changes in circulatory hormone levels. Importantly, chronic exposure of mice to such altered hormone levels eventually led to a dramatic decrease in essential inflammatory cytokines and profound dysregulation of circulatory immune cell profiles.

\section{Materials and methods}

\section{Mice}

All mouse strains were housed under specific pathogen-free (SPF) conditions at the Experimental Centre of the Medical Theoretical Center (MTZ, Technical University of DresdenUniversity Hospital Carl-Gustav Carus, Dresden, Germany). Experiments were performed with male and female mice aged between 8 and 16 weeks. Akr1b7:cre-Phd2/Hif $1^{f f / f f}$ (P2H1) or Akr1b7:cre-Phd2/Phd $3^{\text {ffffff }}(\mathrm{P} 2 \mathrm{P} 3)$ lines were generated by crossing Akr1b7:cre mice [29] to Phd2 $2^{f f f}$, Hiflo $\alpha^{\text {fff }}$ or $P h d 2^{f f f} ; P h d 3^{f / f}$ as previously reported by us [30], and/or the reporter strain $\mathrm{mTmG}$ [31]. All mice described in this report were born in normal Mendelian ratios and were bred on a C57BL/6J background (backcrossed at least 9 times). For each experiment, transgenic mice were compared to littermate controls. Mice were genotyped using primers described in Online Resource 1. Both genders were used in similar amounts and no significant differences between the genders of the same genotype were observed for any of the performed analysis within this study.

Histological analysis of the adrenal gland of Akr1b7:cre$\mathrm{mTmG}^{\mathrm{f} / \mathrm{f}}$ reporter mice revealed zonal variation in the penetrance of cre-recombinase activity in the adrenal cortex of all individual mice $\left(\mathrm{GFP}^{+}\right.$staining). Peripheral blood was drawn from mice by retro-orbital sinus puncture using heparinized micro hematocrit capillaries (VWR, Darmstadt, Germany) and plasma separated and stored at $-80^{\circ} \mathrm{C}$ until further analysis. Mice were killed by cervical dislocation and adrenals were isolated, snap frozen in liquid nitrogen, and stored at $-80^{\circ} \mathrm{C}$ for hormone analysis or gene expression analysis. All mice were bred and maintained in accordance with facility guidelines on animal welfare and with protocols approved by the Landesdirektion Sachsen, Germany. 


\section{Blood analysis}

White blood cells, including neutrophils, eosinophils and lymphocytes were measured in whole blood using a Sysmex automated blood cell counter (Sysmex 117 XE-5000)) [32].

\section{Hormone detection}

Adrenal glands were incubated in disruption buffer (component of Invitrogen ${ }^{\mathrm{TM}}$ Paris $^{\mathrm{TM}}$ Kit, AM 1921, ThermoFisher Scientific, Dreieich, Germany) for 15 min at $4{ }^{\circ} \mathrm{C}$, homogenized in a tissue grinder, followed by incubation for $15 \mathrm{~min}$ on ice, centrifugation and supernatant collection (N.B. and M.P. unpublished results). Adrenal steroid hormones were determined by LC-MS/MS as described elsewhere [33]. Catecholamines, norepinephrine, epinephrine, and dopamine were measured by high-pressure liquid chromatography (HPLC) coupled with electrochemical detection, as previously described [34]. The hormones were measured as ng per $\mu \mathrm{g}$ of total adrenal gland protein, ranging from $\sim 4$ to $\sim 50 \mathrm{ng} /$ adrenal for progesterone; $\sim 10-\sim 1500 \mathrm{ng} / \mathrm{adrenal}$ for corticosterone, and 3- 27 ng/adrenal for aldosterone. All concentrations were normalized to the average value of WTs for every independent experiment; and the average WT value was set as 1 .

\section{RNA extraction and qPCRs}

RNA from adrenal glands and sorted cells was isolated using the RNA Easy Plus micro kit (Qiagen) (Cat. \# 74034Qiagen). cDNA synthesis was performed using the iScript cDNA Synthesis Kit (BIO-RAD, Feldkirchen, Germany). Gene expression levels were determined by performing quantitative real-time PCR using the 'Ssofast Evagreen Supermix' (BIO-RAD, Feldkirchen, Germany). Sequences of primers used are provided in Online Resource 2. Expression levels of genes were determined using the Real-Time PCR Detection System-CFX384 (BIO-RAD, Feldkirchen, Germany). All mRNA expression levels were calculated relative to $\beta 2 \mathrm{M}$ or EF2 housekeeping genes and were normalized using the ddCt method. Relative gene expression was calculated using the $2(-\mathrm{ddCt})$ method, where ddCT was calculated by subtracting the average WT dCT from dCT of all samples individually.

\section{Immunohistochemistry and immunofluorescence}

For preparation of paraffin sections, adrenal glands were isolated, incubated in $4 \%$ formaldehyde at $4{ }^{\circ} \mathrm{C}$ overnight, dehydrated, embedded in paraffin and cut into $5 \mu \mathrm{m}$ sections using a microtome. Sections were rehydrated and subjected to hematoxylin and eosin staining (H\&E). For frozen sections, adrenal glands were embedded in O.C.T Tissue-Tek
(A. Hartenstein GmbH, Würzburg, Germany) and stored at $-20{ }^{\circ} \mathrm{C}$. For $\mathrm{H} \& \mathrm{E}$ staining of frozen sections $(7 \mu \mathrm{m})$, samples were first fixed in cold acetone before staining. For immunofluorescence, sections were fixed in cold acetone, air-dried, washed with phosphate-buffered saline containing $0.1 \%$ Tween-20, blocked with 5\% normal goat serum followed by primary antibody staining (CD31/PECAM-1:500 [35]) or GFP Polyclonal (Antibody ThermoFisher Scientific-1:200) overnight at $4{ }^{\circ} \mathrm{C}$ and subsequent secondary antibody staining. After counterstaining with DAPI, slides were mounted in fluorescent mounting medium and stored at $4{ }^{\circ} \mathrm{C}$ until analysis.

\section{Microscopy}

Both bright-field and fluorescent images were acquired on an ApoTome II Colibri (Carl Zeiss, Jena, Germany). Images were analyzed using either Zen software (Carl Zeiss, Jena, Germany) or Fiji (ImageJ distribution 1.52 K). Fiji was used to quantify lipid droplet sizes and amount of CD31 staining per area.

\section{Meso Scale Discovery}

Plasma was collected from whole blood (3000 RPM for 10 min at $4{ }^{\circ} \mathrm{C}$ ). Meso Scale Discovery (MSD, Rockville, Maryland) was used for quantitative determination of the cytokines (IL-1 $\beta$, IL-4, IL-5, IL-6, KC/GRO, IL-10, and TNF- $\alpha$ ) using $50 \mu$ of plasma in the Proinflammatory Panel 1 (mouse) V-PLEX Kit and MSD plate reader (QuickPlex SQ 120). Cytokine concentrations were calculated by converting the measured MSD signal to $\mathrm{pg} / \mathrm{ml}$ using a standard. All values below blank (control) were considered as zero. Finally, all cytokine concentrations in individual transgenic mice were normalized to the average value of WTs for every independent experiment; and the average WT value was set as 1 .

\section{Next-generation sequencing}

For RNAseq analysis, adrenal glands from Akr1b7:crePhd2/Hifl/mTmG ${ }^{\mathrm{fff} / \mathrm{fff}}$ and Akr1b7:cre-mTmG ${ }^{\mathrm{f} / \mathrm{f}}$ (control) mice were isolated directly into the lysis buffer of the RNeasy Plus Micro Kit, RNA was isolated according to manufacturer's instructions, and SmartSeq2 sequencing was performed [RNAseq data are available at GEO (GSE154032)]. Flow cytometry and cell sorting were performed as described previously [36].

\section{Read quantification}

Kallisto v0.43 was first used to generate an index file from the transcript file, which can be downloaded from:ftp://ftp. 
ebi.ac.uk/pub/databases/gencode/Gencode_mouse/relea se_M12/gencode.vM12.transcripts.fa.gz. Kallisto v0.43 was then run on all the fastq files using parameters "quant-single -175 -s 5 -b 100" to quantify reads for the genes.

\section{Differential gene expression quantification}

Complete cDNA sleuth v0.30.0 (an R package) was used to evaluate differential expression. The command "sleuth_ prep" was run with parameter "gene_mode=TRUE". Two separate error models were fit using "sleuth_fit" wherein the first was a "full" model with gender and experimental condition as covariates, while the second was a "reduced" model with only gender as the covariate. "sleuth_lrt" (Likelihood Ratio Test) was used to evaluate differential gene expression by comparing the full model and the reduced model.

\section{Statistical analyses}

All data are presented as mean \pm SEM. Data (WT control versus transgenic line) were analyzed using the Mann-Whitney $U$ test, unpaired $t$ test with Welch's correction as appropriate (after testing for normality with the $\mathrm{F}$ test) or as indicated in the text. All statistical analyses were performed using GraphPad Prism v7.02 or higher for Windows (GraphPad Software, La Jolla California USA, www.graphpad. com); " $n$ " in the figure legends denotes individual samples.

\section{Results}

\section{A new mouse model to study the effects of HIFa in the adrenal cortex}

We took advantage of the adrenal cortex-specific $A k r l b 7$ :cre recombinase mouse line (no gonadal expression) [30] to investigate the effects of adrenocortical HIF1 $\alpha$ and/or HIF $2 \alpha$ on the structure and functions of the adrenal gland. First, when combined with the $\mathrm{mTmG}$ reporter strain [31], we demonstrate partial targeting of adrenocortical cells as shown previously (Fig. 1a) [30]. We then combined this creline to locally knock-out PHD2, the HIF $\alpha$ 's direct regulator, together with HIF1 $\alpha$; generating the Akr1b7:cre-Phd2/

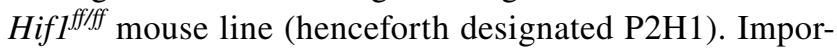
tantly, qPCR analysis using mRNA from whole adrenal glands already revealed significant reduction of Hifl $\alpha$, a clear tendency in reduced $P h d 2$ expression and a substantial increase of Hif $2 \alpha$ mRNA when compared to glands from WT littermates (Fig. 1b). Furthermore, we explored the expression profile of a number of downstream genes known to be transactivated by HIF $2 \alpha$ [37-39] and found a significant increase in Vegfa, Hmoxl, and a trend in Bnip3 levels (Fig. 1c). Taken together, $\mathrm{P} 2 \mathrm{H} 1$ mice exhibit markedly opposite expression levels of Hifl $\alpha$ and Hif $2 \alpha$ confined to adrenocortical cells, which we were even able to define in whole adrenal glands.

\section{Morphological changes in the adrenal cortex of P2H1 mice}

To evaluate the impact of changes in HIF $1 \alpha$ and/or HIF $2 \alpha$ activity in adrenocortical cells, we analyzed adrenal gland morphology using H\&E staining on paraffin sections but found no differences between P2H1 mice and WT littermates in the structure of the adrenal gland, especially, at the side of the cortex of $\mathrm{P} 2 \mathrm{H} 1$ mice in comparison to WT littermates (Fig. 1d). As we detected a significant increase in Vegfa in the adrenal glands of $\mathrm{P} 2 \mathrm{H} 1$ mice, we used CD31 staining to quantify endothelial cells but detected no significant differences between P2H1 and WT mice (Fig. 1e). Remarkably, H\&E staining on cryosections of $\mathrm{P} 2 \mathrm{H} 1$ adrenal glands revealed significantly smaller lipid droplets in the adrenocortical cells (Fig. 1f), an effect that is reported to be correlated with greater conversion of cholesterol into pregnenolone [10].

\section{Modulation of HPPs in the adrenal cortex enhances synthesis and circulatory levels of steroid hormones}

Next, to verify if the observed changes in lipid droplets indeed led to changes in steroidogenesis, we quantified steroid hormones and their precursor levels by LC-MS/MS in the adrenal gland and in plasma. Quantification revealed a significant increase in virtually all the hormones tested in P2H1 adrenal glands compared to WT littermates (Fig. 2a), and importantly, a corresponding increase of progesterone, corticosterone, and aldosterone was found in the plasma (Fig. 2b). These observations clearly indicate that central HPPs have an impact on steroidogenesis in the murine adrenal gland and on circulatory levels of steroid hormones.

\section{Downstream effects of the chronic increase in the steroidogenesis}

Previous reports have stated that glucocorticoids can regulate catecholamine production in the adrenal medulla [40, 41]; therefore, we also measured dopamine, norepinephrine, and epinephrine levels in the samples used to quantify steroid levels (as above). However, we found no difference between P2H1 and WT littermates in any of the catecholamines quantified (Supplementary Fig. S1a). Further, although increased steroid levels often result in other systemic changes, $\mathrm{P} 2 \mathrm{H} 1$ mice displayed no difference in serum potassium levels or blood glucose levels compared to WT littermates (Supplementary Fig. S1b, c). Taken together, in contrast to the systemic effects induced by acute and high 
a

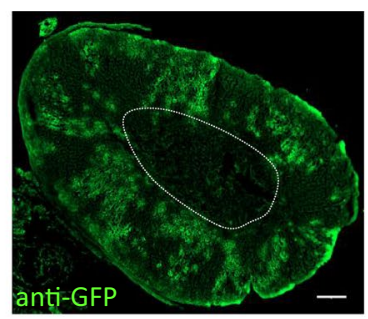

C
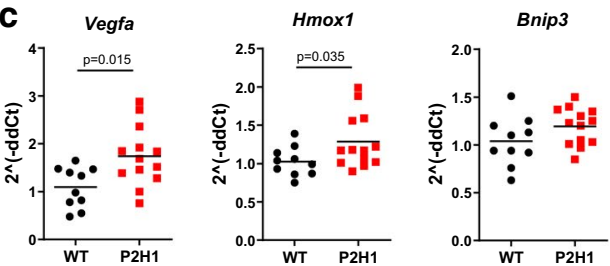

d

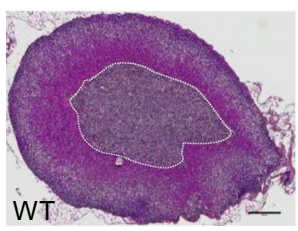

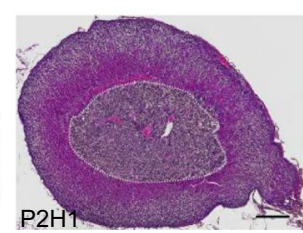

b
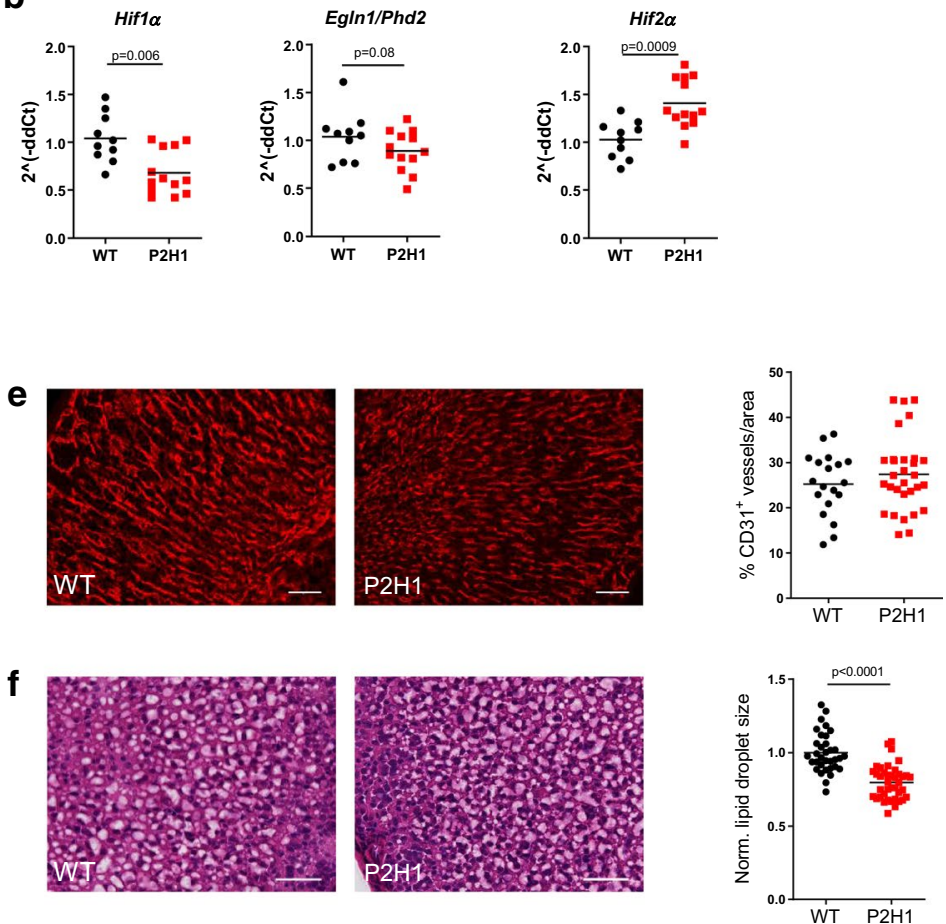

Fig. 1 Characterization of the Akr1b7:cre-P2H1 ${ }^{\mathrm{ff} / \mathrm{ff}}$ mouse line with cortex-specific targeting of hypoxia pathway proteins. a Representative immunofluorescent image of anti-GFP stained (GFP+) area in the adrenal cortex of the Akr1b7:cre-mTmG mouse line. Region enclosed within the white dotted line represents the medulla and it demarcates the medulla from the cortex (scale bar, $100 \mu \mathrm{m}$ ). b qPCRbased mRNA expression analysis of Hifl $\alpha$, Phd 2 and Hif $2 \alpha$ in entire adrenal tissue from P2H1 mice and WT littermates $(n=10-13)$. Relative gene expression was calculated using the $2^{\wedge}\left(^{-} \mathrm{ddCt}\right)$ method. The graphs represent data from 2 independent experiments. c Relative gene expression analysis using mRNA from the entire adrenal tissue in P2H1 mice and their WT counterparts $(n=10-13)$. All graphs represent data from 2 independent experiments. $\mathbf{d}$ Representative images (magnification 20x) of paraffin sections of adrenal glands (H\&E)

levels of circulatory cortical hormones (e.g., corticosterone, aldosterone) [3, 4], the P2H1 mice display moderate but chronically enhanced levels of cortical hormones at the described time points.

\section{Loss of PHD2/HIF1a in adrenocortical cells impacts gene expression related to steroidogenesis}

Previous in vitro studies and reports on HIF $1 \alpha$ alterations in zebrafish larvae have suggested negative regulation of Star, the mitochondrial cholesterol transporter [7, 19, 22]. However, data on the effects of HPP alterations in adrenal cortex of mice is scant at best. Therefore, to assess the impact of HIF $1 \alpha$-deletion and/or HIF $2 \alpha$-upregulation in adrenal cortical cells, we performed broad transcription analysis of proteins/enzymes involved in steroidogenesis using mRNA from 8-week-old WT and P2H1 mice (scale bars represent $100 \mu \mathrm{m}$ ). e Representative immunofluorescent images of $\mathrm{CD} 31^{+}$endothelial cell staining in adrenal gland sections from WT and $\mathrm{P} 2 \mathrm{H} 1$ mice (scale bars represent $50 \mu \mathrm{m}$ ). Graph in the right-side panel represents quantification of $\mathrm{CD} 31^{+}$area as a fraction of total tissue area. Each data point represents a single measurement of the cortical area in the adrenal gland (collection of $n=6$ vs 11 individual mice). f Representative images of cryosections of WT and P2H1 adrenal glands (H\&E) (scale bars represent $50 \mu \mathrm{m}$ ). Graph in the right-side panel represents the normalized average size of an individual lipid droplet per section of adrenal gland tissue in WT versus $\mathrm{P} 2 \mathrm{H} 1$ mice. Measurements were made from 6 sections per mouse. ( $n=8$ individual adrenals per genotype). The graphs in $\mathbf{e}$ and $\mathbf{f}$ are representative of 2 independent experiments

from whole adrenals. Our results reveal that almost all of the gene products tested showed either a significant increase or a tendency to do so, including key enzymes such as Star, Cyp11a1, Cyp21al and Cyp11b1 (Fig. 3a).

To further characterize this phenotype driven by the HPPs, we performed next-generation sequencing (NGS) and compared the steady-state transcriptomes of $\mathrm{P} 2 \mathrm{H} 1$ and WT littermate mice (Fig. 3b). For this, we specifically created the Akr1b7:cre-PHD2/HIF 1/mTmG $G^{\text {fff/fff }}$ mouse line (P2H1 reporter mice) to study only targeted adrenal cortex cells, with Akr1b7:cre-mTmG $G^{\mathrm{f} / \mathrm{f}}$ animals used as controls. Bulk RNAseq was performed on $\mathrm{GFP}^{+}$-sorted adrenal gland cells as described previously [42] and gene signatures of the various lineages were evaluated using Enrichr or gene set enrichment analyses (GSEA). Concurring with the previous results, we found a number of significant signatures 

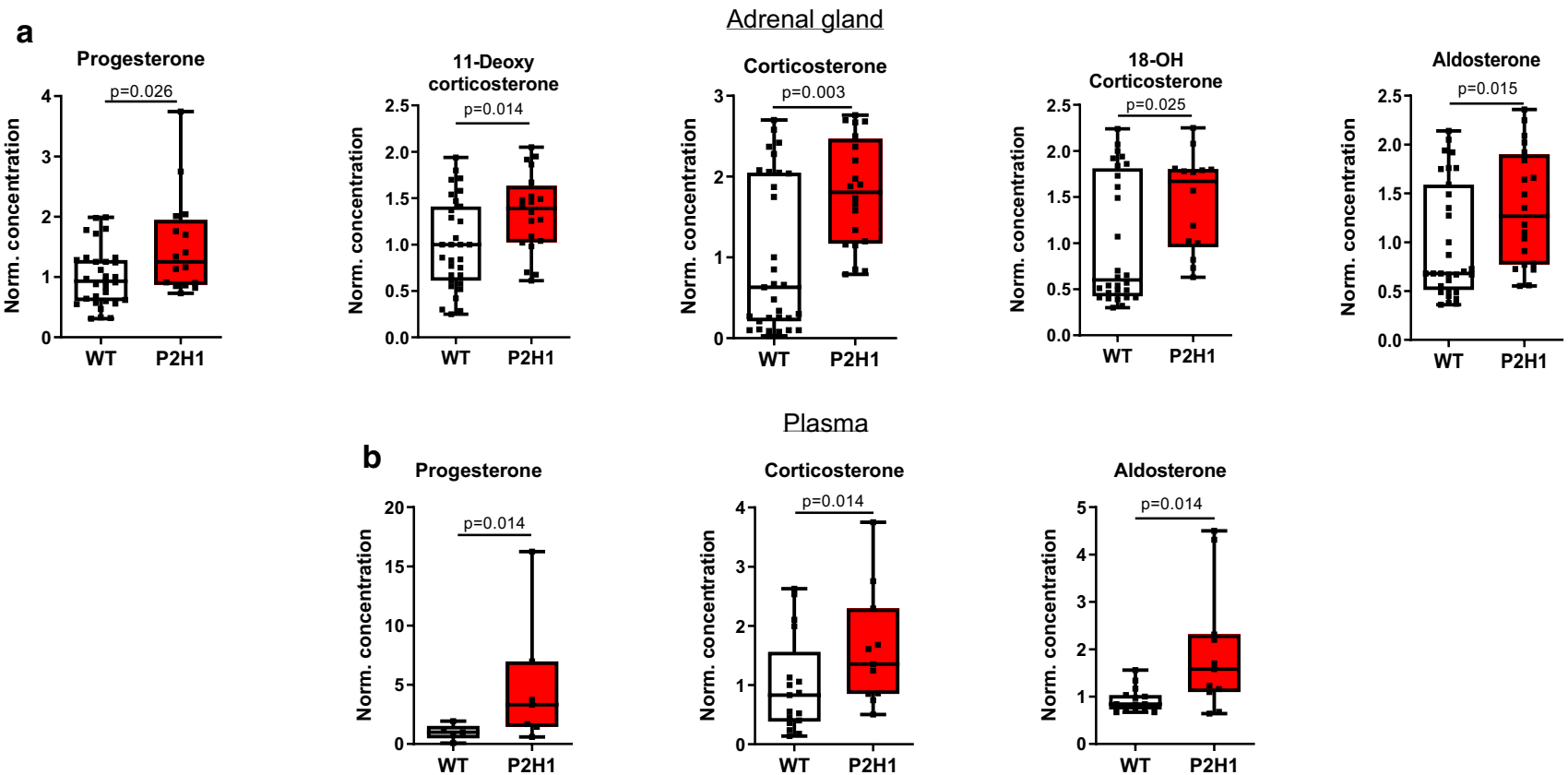

Fig. 2 Adrenal cortex-specific loss of PHD2 and HIF1 leads to enhanced steroidogenesis in $\mathrm{P} 2 \mathrm{H} 1$ mice. a Box and whisker plots showing steroid hormone measurements in adrenal glands from WT mice and compared to littermate $\mathrm{P} 2 \mathrm{H} 1$ mice $(n=20-31$ individual

related to the process of steroid synthesis in adrenocortical cells or their response to it (Fig. 3c-d). Notably, GSEA also revealed known HIF-dependent associations including, actin cytoskeleton [43, 44], adipogenesis [45] and oxidative phosphorylation [46] (Fig. 3e). Furthermore, P2H1 cortical cells also displayed a positive signature related to the regulation of nuclear $\beta$-catenin signaling, which is known to be primarily activated in the zona glomerulosa with potential hyperplasic effects [47] (Fig. 3f). Thus, hypoxia pathway proteins are directly involved in the regulation of known signaling pathways driving adrenal gland homeostasis.

\section{Modulated adrenocortical HIFs skew cytokine production and leukocyte numbers}

As several studies have reiterated a crucial role for glucocorticoids in immunomodulation [3, 48], and Cushing's syndrome has been described to be accompanied by immune deficiency $[3,49,50]$, we measured circulatory cytokine levels. We report a substantial overall decrease in the levels of both pro- and anti-inflammatory cytokines, with the exception of the chemokine and neutrophil attractant CXCL1, which increased almost twofold (Fig. 4a). Glucocorticoids have been repeatedly shown to promote apoptosis-mediated reduction of lymphocytes [51] and eosinophil reduction [52], along with neutrophilia due to enhanced recruitment from the bone marrow [53]. Therefore, we enumerated the various adrenal glands). b Box and whisker plots showing steroid hormone measurements in the plasma of individual mice $(n=5-17)$. All data were normalized to the average value of WT mice and graphs represent results of pooled data of at least 3 independent experiments

white blood cell (WBC) fractions in $\mathrm{P} 2 \mathrm{H} 1$ mice and compared it with that of their WT littermates, which revealed a significant reduction in both lymphocyte and eosinophil fractions (Fig. 4b) accompanied by marked elevation in neutrophils (> 70\% compared to WT) (Fig. 4c). Taken together, our data reveal a critical role for HIFs in steady-state cytokine levels and leukocyte numbers, probably through alterations in steroidogenesis pathways.

\section{HIF1a inversely regulates steroidogenesis}

To extend our understanding of the role of HIF1 $\alpha$ and/or HIF2 $\alpha$ in adrenocortical cells, we created the Akr1b7:cre$\mathrm{PHD} 2 / \mathrm{PHD} 3^{\mathrm{ff} / \mathrm{ff}}$ mouse line (designated as P2P3) to locally increase both HIF1 $\alpha$ and HIF2 $\alpha$ (Supplementary Fig. S2). Intriguingly and in contrast to hormone levels in the adrenal glands of the $\mathrm{P} 2 \mathrm{H} 1$ mice, $\mathrm{P} 2 \mathrm{P} 3$ adrenal glands displayed a marked decrease in corticosterone and aldosterone levels, along with a cognate reduction in their precursors, both in the adrenal gland (Fig. 5a) and in circulation (Fig. 5b). These results clearly suggest that steroidogenesis is dependent on HIF1 $\alpha$ but not HIF2 $\alpha$. To further confirm this observation, we performed mRNA expression analyses to identify the levels of central enzymes, similar to that performed in $\mathrm{P} 2 \mathrm{H} 1$ mice, and demonstrate an overall decrease in these enzymes (Fig. 6a). This observation is contrary to that seen in the $\mathrm{P} 2 \mathrm{H} 1$ mice but fits neatly with the observed reduction in 
a
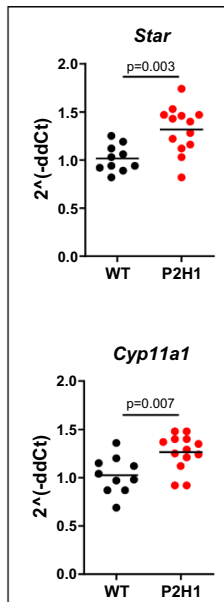
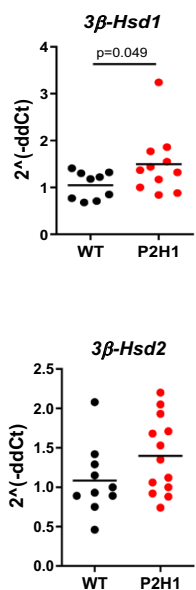

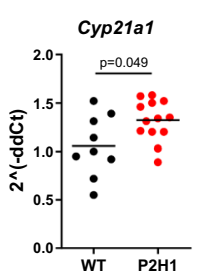

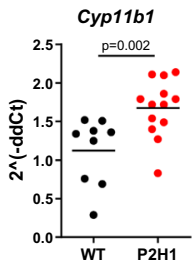

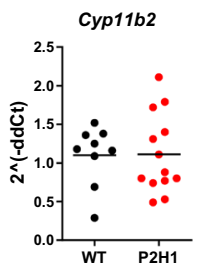

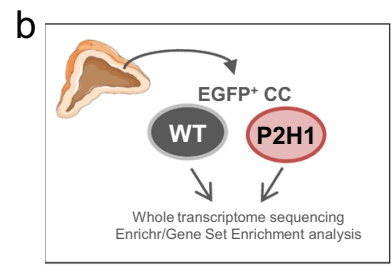

\section{C}

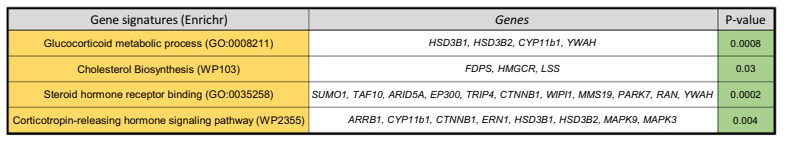

d

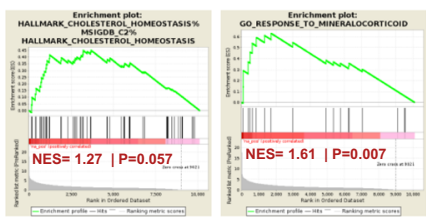

e

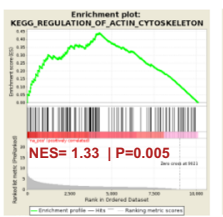

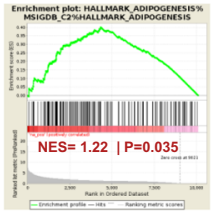

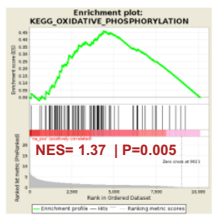

f

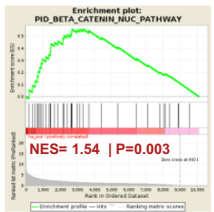

Fig. 3 Gene expression analysis of P2H1 adrenocortical cells. a Gene expression analysis of enzymes involved in the steroidogenesis pathway using mRNA from whole adrenals from $\mathrm{P} 2 \mathrm{H} 1$ mice and WT counterparts $(n=10-13)$. All graphs are the result of 2 independent experiments. b Schematic overview of the RNAseq approach which

steroid levels in the $\mathrm{P} 2 \mathrm{P} 3$ mice, thereby underscoring the central role of HIF1 $\alpha$ (Fig. 6b). Finally, we tested the same set of pro- and anti-inflammatory cytokines as for $\mathrm{P} 2 \mathrm{H} 1$ mice. In line with all previous results, we show an overall increase in cytokines in the plasma of $\mathrm{P} 2 \mathrm{P} 3$ mice versus their WT littermate controls (Fig. 7a). However, no changes were found in CXCL1 protein, which was also reflected in the lack of difference in circulating neutrophils (Supplementary Fig. S3).

\section{Discussion}

Here, using a unique collection of adrenocortical-specific transgenic mouse lines, we identify HIF1 $\alpha$ as a central transcription factor that regulates the steroidogenesis pathway by regulating key enzymes. Notably, this directly modifies the entire spectrum of steroid hormones, both in the adrenal compared sorted $\mathrm{GFP}^{+}$cells from WT controls and P2H1 mice $(n=3)$. c Gene signature analysis using Enrichr. d Gene set enrichment analyses (GSEA) showed positive signatures for steroidogenesis-related pathways. e Prominent HIF-related pathways. f The $\beta$-catenin nuclear pathway

gland and in circulation, which eventually impacts the availability of a variety of cytokines.

Studies on the role of HIFs in the regulation of steroidogenesis in vivo are few, apart from those in zebra fish larvae that describe differential regulation of the enzymes involved in the steroid pathway [7, 20, 22]. However, to the best of our knowledge, there are no mouse models to study the role of HPPs in adrenal cortical cells. Undoubtedly, such models would help us to better understand the crosstalk between HPPs and adrenal steroid metabolism, while simultaneously serving as an essential tool to study the pathophysiology of multiple conditions associated with dramatically altered steroid hormone levels [2]. Ablation of HIF1 $\alpha$ revealed an important role for this transcription factor in steroidogenesis, which concurs with results from previous studies [22, 54]. Our findings that HIF $1 \alpha$ deletion results in the upregulation of mRNA of a vast majority of steroid-related enzymes appear counterintuitive. However, Wang and colleagues 

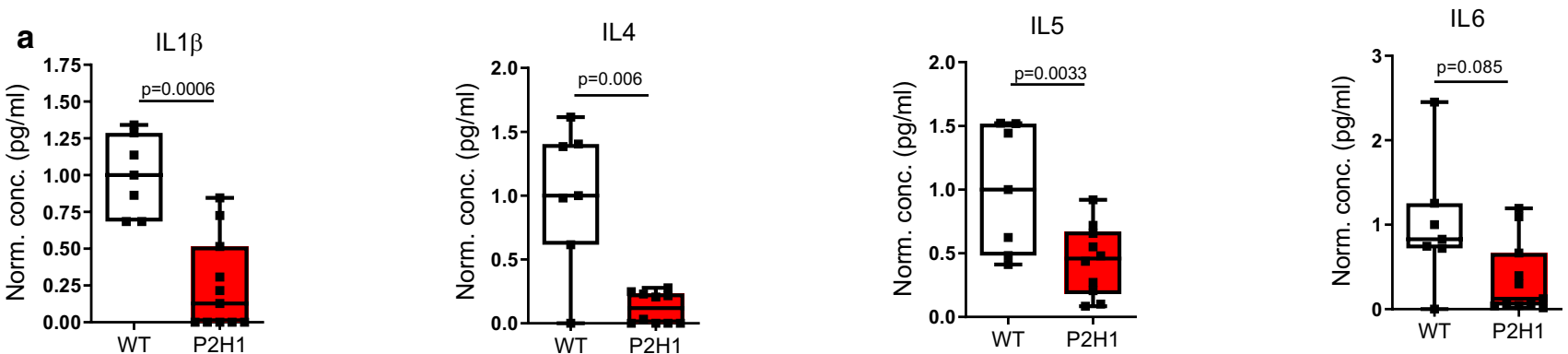

IL10

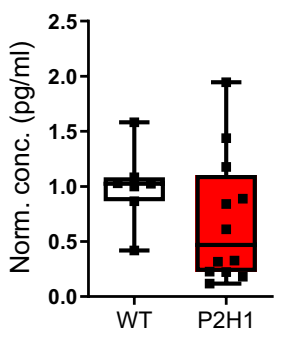

b

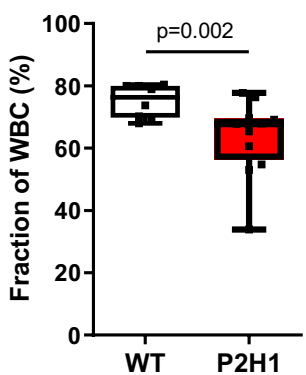

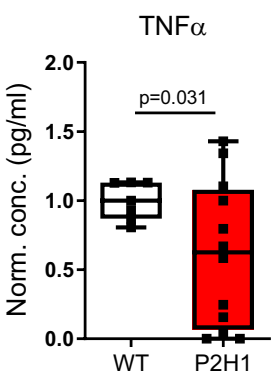

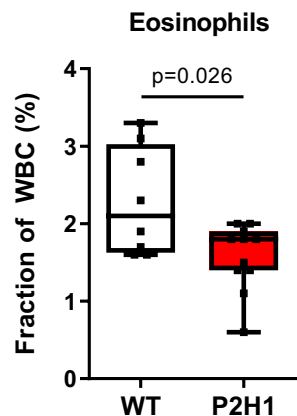

CXCL1

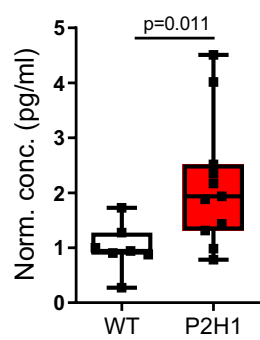

C

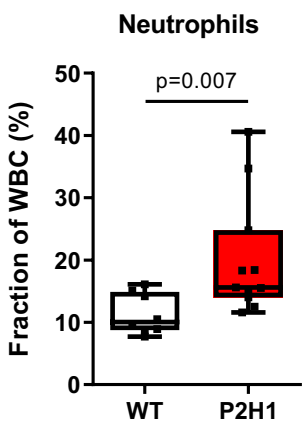

Fig. 4 Immune system changes in $\mathrm{P} 2 \mathrm{H} 1$ mice. a Box and whisker plots representing levels of pro/anti-inflammatory cytokines measured in the plasma of P2H1 mice and WT littermate controls $(n=7-12)$. All data were normalized to the average value seen in WT mice. Each dot represents data from one animal. b Box and whisker plots show-

recently described three HIF1-binding sites (HREs) in the promoter region of Star and a negative regulatory effect of HIF1 on Star transcription and synthesis [19]. Furthermore, a number of putative HREs are predicted in the promoter of other steroidogenic enzymes (e.g., in Cyp11b2 (D.W., A.S and B.W. unpublished results). In-depth analysis of these regions is, therefore, essential to better comprehend the direct negative regulation of steroidogenesis-related enzymes by HIF1. On the other hand, also an indirect effect with potential involvement of one or more transcriptional repressors could play a role $[55,56]$. This type of transcriptional regulation of adrenal steroidogenesis has already been suggested with miRNAs, some of which might be directly regulated by hypoxia/HIF1 [57, 58]. Taken together, more in-depth studies are required to completely understand the direct or indirect impact of HIF1 $\alpha$ on the expression patterns of steroidogenesis-related enzymes. ing percentage lymphocytes and eosinophils in circulation which revealed reduced fractions in $\mathrm{P} 2 \mathrm{H} 1$ mice compared to WT controls. c Greater numbers of circulating neutrophils in $\mathrm{P} 2 \mathrm{H} 1$ mice compared to WT littermates. All graphs represent pooled results of 2 independent experiments

Our RNAseq analysis of Akr1b7 ${ }^{+} \mathrm{P} 2 \mathrm{H} 1$ adrenocortical cells not only unearthed several genetic signatures directly associated with steroidogenesis, but a number of GSEAs revealed prominent HIF-dependent phenotypes previously identified in a variety of other cell types. Recently, we have described a significant role for HIF $2 \alpha$ in the regulation of the actin cytoskeleton, especially in facilitating enhanced neutrophil migration through very confined environments [44], HIF $1 \alpha$ has also been associated with cytoskeleton structure and functionality in a number of cell lineages (reviewed in [43]); this is apart from its role in energy metabolism wherein enhanced oxidative phosphorylation has been demonstrated in various HIF1 $\alpha$-deficient cell lineages [46]. Therefore, it will be of interest to further explore changes in multiple metabolites that are directly or indirectly associated with the TCA 

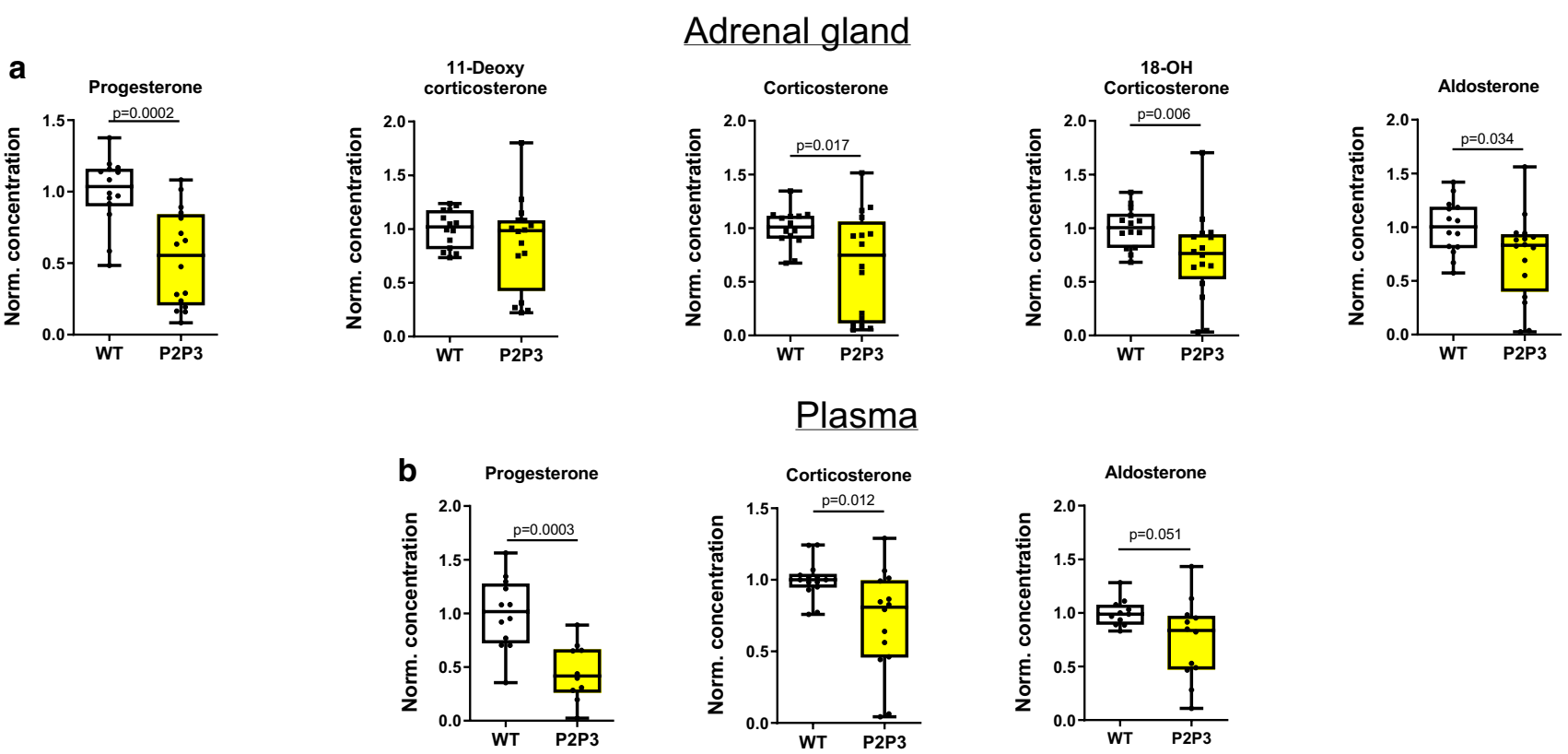

Fig. 5 Adrenal cortex-specific loss of PHD2 and PHD3 leads to reduced steroidogenesis in mice. a Box and whisker plots showing steroid hormone levels in the adrenal glands of WT mice and compared to that of littermate $\mathrm{P} 2 \mathrm{H} 1$ mice $(n=14-16$ individual adrenal

cycle to find a potential link with the overall changes described here.

Glucocorticoids and aldosterone are both essential for homeostasis and their substantial increase in $\mathrm{P} 2 \mathrm{H} 1$ mice was intriguing, given their pivotal role in immune suppression [3,59] and blood pressure regulation, respectively. Previous studies have shown that aldosterone not only increases the expression of the potassium channels that secrete potassium but also stimulates K-absorptive pumps in the renal cortex and medulla, thereby stabilizing and maintaining renal potassium excretion [60], a situation we also observed in the $\mathrm{P} 2 \mathrm{H} 1$ mice. The significant increase in glucocorticoids upon HIF1 $\alpha$ deletion was clearly associated with immunosuppression, as demonstrated by an overall decrease in both pro- and antiinflammatory cytokines in circulation, and these observations mirror other reports of immune modulation due to enhanced glucocorticoid levels. Such glucocorticoid elevation can eventually even result in dramatic immune deficiency, for example, as seen in Cushing's disease [3, 50, 59].

Intriguingly, we found serum CXCL1 to be significantly enhanced in $\mathrm{P} 2 \mathrm{H} 1$ mice, probably because as a central neutrophil attractant it was associated with the massive increase in circulatory neutrophils seen in these mice. It is known that enhanced neutrophil recruitment glands). b Box and whisker plots showing steroid hormone measurements in the plasma of individual mice $(n=10-12)$. All data were normalized to the average value of WT mice and graphs represent results of pooled data of at least 3 independent experiments

from the bone marrow is directly associated with glucocorticoids [53], as is their overall survival [61].

An essential role of HIF1 $\alpha$, but not HIF $2 \alpha$, in the modulation of enzymes and adrenocortical hormones could be further corroborated by the contrasting results seen in the P2P3 mice. Specifically, compared to $\mathrm{P} 2 \mathrm{H} 1$ mice, the expression profile of virtually all steroidogenesis-regulating enzymes was dramatically inverted in the $\mathrm{P} 2 \mathrm{P} 3$ mice, which resulted in an overall impairment of the steroidogenesis pathway (Fig. 7b) and an increase in the levels of circulating cytokines. Therefore, these mouse lines will also be helpful to study the potential impact of substantially modulated steroid levels in a variety of clinically relevant diseases including metabolic and auto-immune disorders.

In summary, we reveal a prominent role for HIF $1 \alpha$ as a central regulator of steroidogenesis in mice as two distinct transgenic mouse lines showed persistent but contrasting changes in corticosterone and aldosterone concentrations at levels sufficient to modulate systemic cytokine levels and leukocyte numbers. These $\mathrm{P} 2 \mathrm{H} 1$ and $\mathrm{P} 2 \mathrm{P} 3$ mouse strains will be of significant importance in further exploring the impact of HIF1 $\alpha$ in adrenocortical cells and as an important component in regulation of steroidogenesis-mediated systemic effects. 

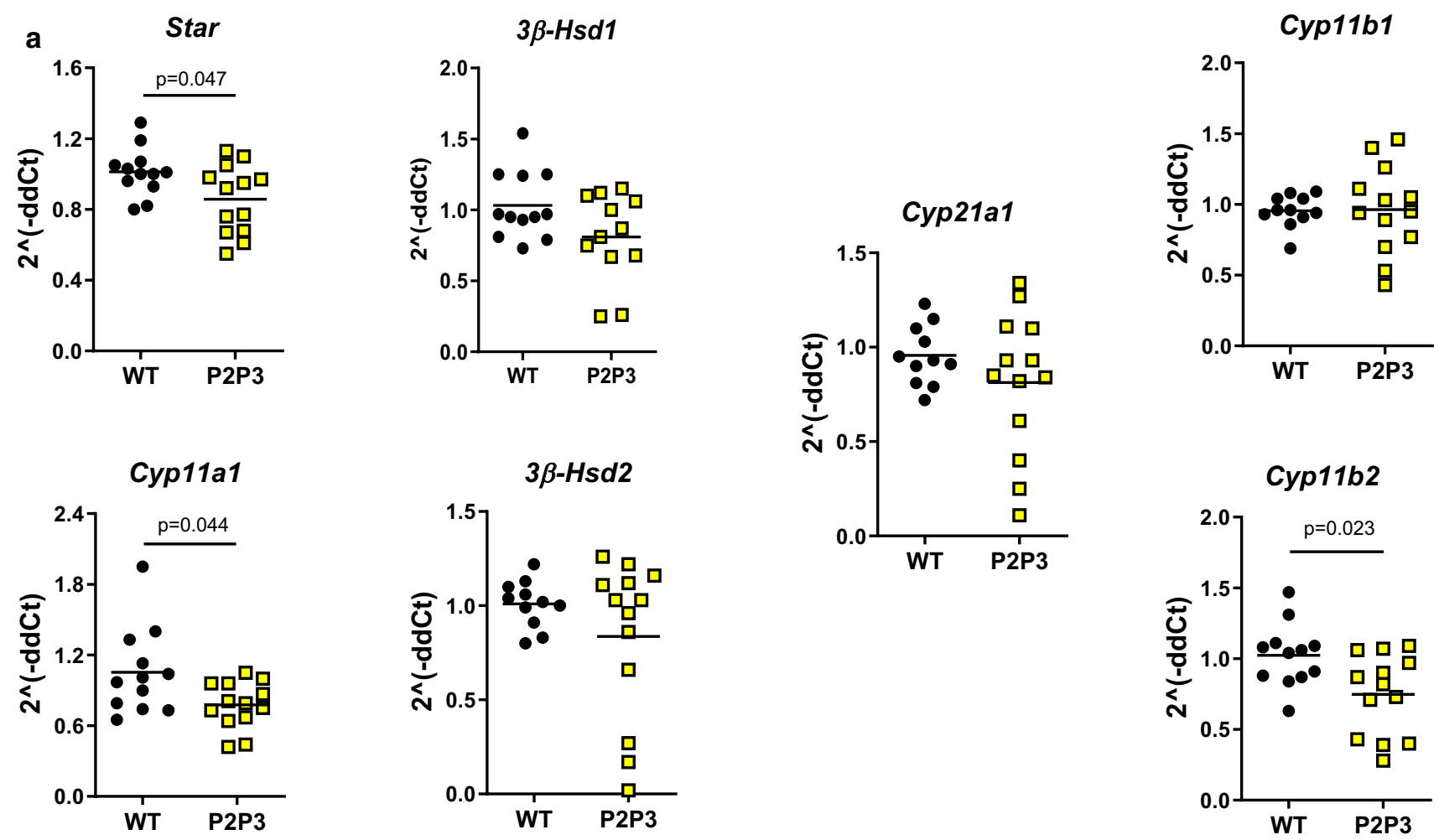

b

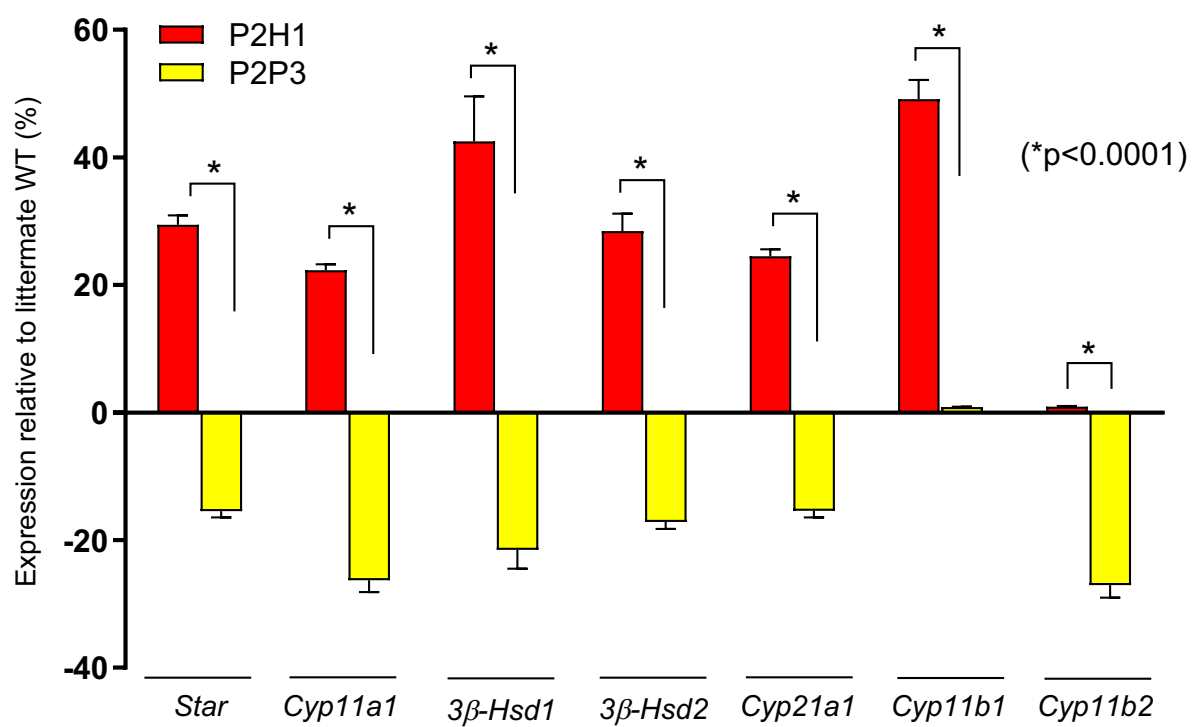

Fig. 6 Inverse regulation of steroidogenesis in P2P3 mice compared to $\mathrm{P} 2 \mathrm{H} 1$ mice. a Gene expression analysis of enzymes involved in the steroidogenesis pathway in $\mathrm{P} 2 \mathrm{P} 3$ mice and their WT counterparts $(n=12-13)$ was performed on mRNA from entire adrenal glands. All graphs represent pooled data from at least 3 independent experiments. b Relative expression profile of all genes analyzed from the adrenal glands of $\mathrm{P} 2 \mathrm{H} 1$ and $\mathrm{P} 2 \mathrm{P} 3$ mice and compared to their respective WT littermates. Statistical significance was defined using an unpaired multiple $t$ test $(n=13$; Benjamini, Krieger and Yekutieli method; $* p<0.0001$ for all individual genes) 

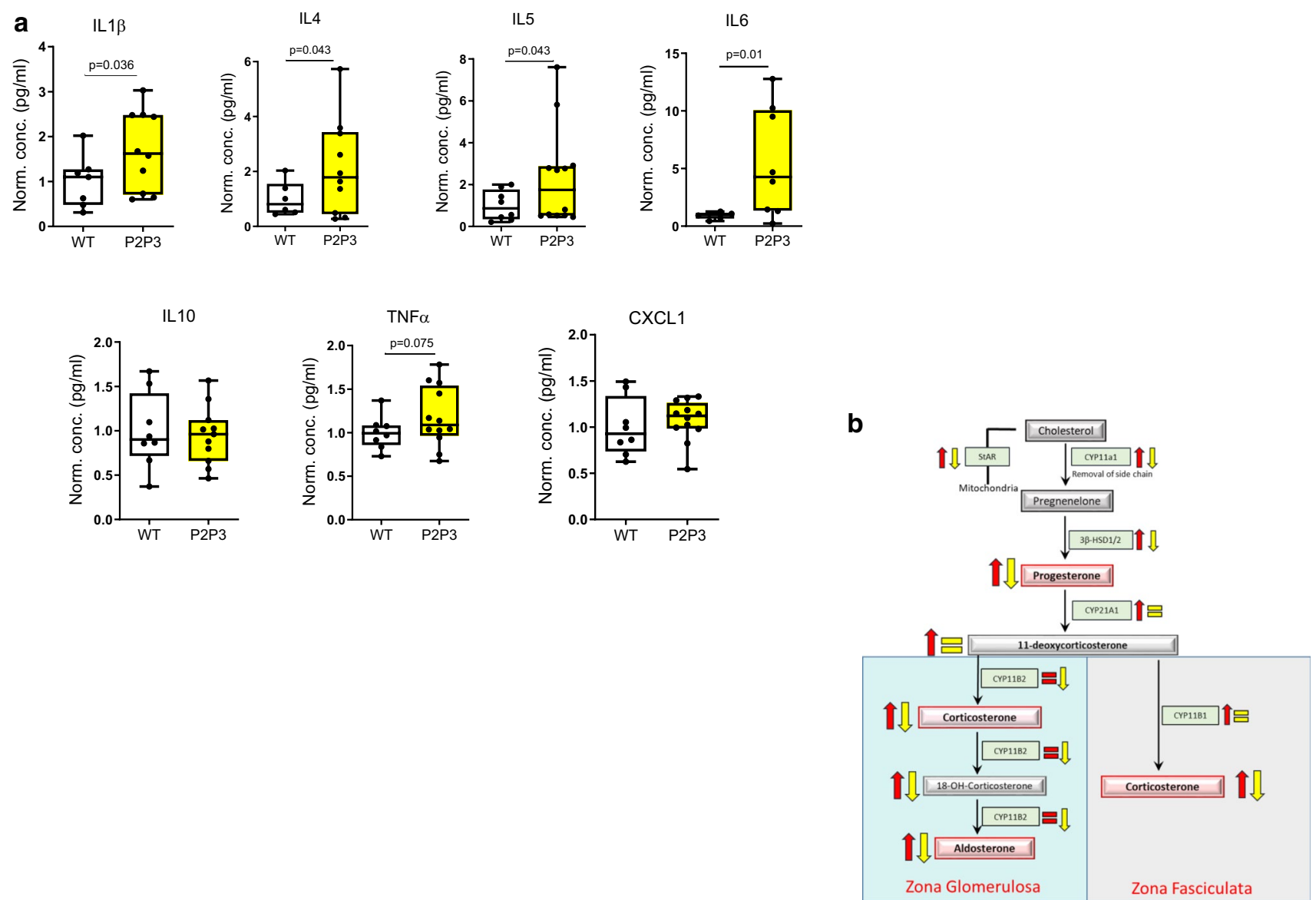

Fig. 7 Immune system changes in $\mathrm{P} 2 \mathrm{P} 3$ mice. a Box and whisker plots representing levels of pro/anti-inflammatory cytokines measured in the plasma of P2P3 mice and WT littermate controls $(n=6-13)$. Each dot represents data from one animal. All data were normalized to the average value seen in WT mice and one-tailed hypothesis tests

Acknowledgements This work was supported by grants from the DFG (German Research Foundation) within the CRC/Transregio 205/1, Project No. 314061271-TRR205, "The Adrenal: Central Relay in Health and Disease" (A02) to B.W., T.C, A-E-A.; B.W. was supported by the Heisenberg program, DFG, Germany; WI3291/5-1 and 12-1). We would like to thank Dr. Vasuprada Iyengar for English Language and content editing.

Author contributions DW designed and performed the majority of experiments, analyzed data, and contributed in writing the manuscript. JS, DK, and AK performed experiments and analyzed data. AMe designed several mouse lines and contributed to the discussion. $\mathrm{NB}, \mathrm{AN}, \mathrm{AEA}$ and TC provided tools and contributed to the discussion. G.E. and M.P. provided tools, analyzed data and contributed to the discussions. VIA, LGP-R and MT contributed to the discussions. A.Ma. provided essential tools. AS performed deep sequencing analysis. BW designed and supervised the overall study, analyzed data, and wrote the manuscript. were performed. All graphs represent samples of different litters. b Schematic overview of all changes in adrenocortical enzymes and their corresponding hormones and intermediates reported here in P2H1 (red) and P2P3 (yellow) mice

Funding This work was supported by grants from the DFG (German Research Foundation) within the CRC/Transregio 205/1, Project No. 314061271-TRR205, "The Adrenal: Central Relay in Health and Disease" (A02) to B.W., T.C, A-E-A.; B.W. was supported by the Heisenberg program, DFG, Germany; WI3291/5-1 and 12-1). We would like to thank Dr. Vasuprada Iyengar for English Language and content editing.

Availability of data and materials All data and material are available upon request to ben.wielockx@tu-dresden.de.

Ethics approval and consent for publication All mice were bred and maintained in accordance with facility guidelines on animal welfare and with protocols approved by the Landesdirektion Sachsen, Germany. All the authors have agreed to be part of the current publication.

Consent to participate All the authors have agreed to participate in the study. 
Conflict of interest The authors have declared that no conflict of interest exists.

Open Access This article is licensed under a Creative Commons Attribution 4.0 International License, which permits use, sharing, adaptation, distribution and reproduction in any medium or format, as long as you give appropriate credit to the original author(s) and the source, provide a link to the Creative Commons licence, and indicate if changes were made. The images or other third party material in this article are included in the article's Creative Commons licence, unless indicated otherwise in a credit line to the material. If material is not included in the article's Creative Commons licence and your intended use is not permitted by statutory regulation or exceeds the permitted use, you will need to obtain permission directly from the copyright holder. To view a copy of this licence, visit http://creativecommons.org/licenses/by/4.0/.

\section{References}

1. Miller WL, Auchus RJ (2011) The molecular biology, biochemistry, and physiology of human steroidogenesis and its disorders. Endocr Rev 32(1):81-151. https://doi.org/10.1210/ er.2010-0013

2. Cain DW, Cidlowski JA (2017) Immune regulation by glucocorticoids. Nat Rev Immunol 17(4):233-247. https://doi.org/10.1038/ nri.2017.1

3. Straub RH, Cutolo M (2016) Glucocorticoids and chronic inflammation. Rheumatology. https://doi.org/10.1093/rheumatology/ kew348

4. Faught E, Vijayan MM (2018) The mineralocorticoid receptor is essential for stress axis regulation in zebrafish larvae. Sci Rep 8(1):18081. https://doi.org/10.1038/s41598-018-36681-w

5. Gallo-Payet N, Battista MC (2014) Steroidogenesis-adrenal cell signal transduction. Compr Physiol 4(3):889-964. https://doi. org/10.1002/cphy.c130050

6. Raff H, Kohandarvish S, Jankowski A (1990) The effect of oxygen on aldosterone release from bovine adrenocortical cells in vitro:PO2 versus steroidogenesis*. Endocrinology 127(2):682687. https://doi.org/10.1210/endo-127-2-682

7. Tan T, Yu RMK, Wu RSS, Kong RYC (2017) Overexpression and knockdown of hypoxia-inducible factor 1 disrupt the expression of steroidogenic enzyme genes and early embryonic development in zebrafish. Gene Regul Syst Bio 11:1177625017713193. https:// doi.org/10.1177/1177625017713193

8. Nusrin S, Tong SK, Chaturvedi G, Wu RS, Giesy JP, Kong RY (2014) Regulation of CYP11B1 and CYP11B2 steroidogenic genes by hypoxia-inducible miR-10b in H295R cells. Mar Pollut Bull 85(2):344-351. https://doi.org/10.1016/j.marpo lbul.2014.04.002

9. Bruder ED, Nagler AK, Raff H (2002) Oxygen-dependence of ACTH-stimulated aldosterone and corticosterone synthesis in the rat adrenal cortex: developmental aspects. J Endocrinol 172(3):595-604. https://doi.org/10.1677/joe.0.1720595

10. Lorente M, Mirapeix RM, Miguel M, Longmei W, Volk D, Cervos-Navarro J (2002) Chronic hypoxia induced ultrastructural changes in the rat adrenal zona glomerulosa. Histol Histopathol 17(1):185-190. https://doi.org/10.14670/HH-17.185

11. Sormendi S, Wielockx B (2018) Hypoxia pathway proteins as central mediators of metabolism in the tumor cells and their microenvironment. Front Immunol 9:40. https://doi.org/10.3389/fimmu .2018 .00040

12. Wielockx B, Grinenko T, Mirtschink P, Chavakis T (2019) Hypoxia pathway proteins in normal and malignant hematopoiesis. Cells. https://doi.org/10.3390/cells8020155
13. Schodel J, Oikonomopoulos S, Ragoussis J, Pugh CW, Ratcliffe PJ, Mole DR (2011) High-resolution genome-wide mapping of HIF-binding sites by ChIP-seq. Blood 117(23):e207-217. https:// doi.org/10.1182/blood-2010-10-314427

14. Smythies JA, Sun M, Masson N, Salama R, Simpson PD, Murray E, Neumann V, Cockman ME, Choudhry H, Ratcliffe PJ, Mole DR (2019) Inherent DNA-binding specificities of the HIF-1alpha and HIF-2alpha transcription factors in chromatin. EMBO Rep. https://doi.org/10.15252/embr.201846401

15. Coffelt SB, Wellenstein MD, de Visser KE (2016) Neutrophils in cancer: neutral no more. Nat Rev Cancer 16(7):431-446. https:// doi.org/10.1038/nrc.2016.52

16. Wiesener MS, Jürgensen JS, Rosenberger C, Scholze C, Hörstrup JH, Warnecke C, Mandriota S, Bechmann I, Frei UA, Pugh CW, Ratcliffe PJ, Bachmann S, Maxwell PH, Eckardt K-U (2003) Widespread, hypoxia-inducible expression of HIF-2 $\alpha$ in distinct cell populations of different organs. FASEB J 17(2):271-273. https://doi.org/10.1096/fj.02-0445fje

17. Stroka DM, Burkhardt T, Desbaillets I, Wenger RH, Neil DA, Bauer C, Gassmann M, Candinas D (2001) HIF-1 is expressed in normoxic tissue and displays an organ-specific regulation under systemic hypoxia. FASEB J 15(13):2445-2453

18. Wiesener MS, Jürgensen JS, Rosenberger C, Scholze CK, Hörstrup JH, Warnecke C, Mandriota S, Bechmann I, Frei UA, Pugh CW, Ratcliffe PJ, Bachmann S, Maxwell PH, Eckardt K-U (2003) Widespread hypoxia-inducible expression of HIF-2alpha in distinct cell populations of different organs. FASEB J 17(2):271-273

19. Wang X, Zou Z, Yang Z, Jiang S, Lu Y, Wang D, Dong Z, Xu S, Zhu L (2018) HIF 1 inhibits StAR transcription and testosterone synthesis in murine Leydig cells. J Mol Endocrinol. https://doi. org/10.1530/JME-18-0148

20. Kowalewski MP, Gram A, Boos A (2015) The role of hypoxia and HIF1alpha in the regulation of STAR-mediated steroidogenesis in granulosa cells. Mol Cell Endocrinol 401:35-44. https://doi. org/10.1016/j.mce.2014.11.023

21. Yamashita K, Ito K, Endo J, Matsuhashi T, Katsumata Y, Yamamoto T, Shirakawa K, Isobe S, Kataoka M, Yoshida N, Goto S, Moriyama H, Kitakata H, Mitani F, Fukuda K, Goda N, Ichihara A, Sano M (2020) Adrenal cortex hypoxia modulates aldosterone production in heart failure. Biochem Biophys Res Commun 524(1):184-189. https://doi.org/10.1016/j.bbrc.2020.01.088

22. Marchi D, Santhakumar K, Markham E, Li N, Storbeck K-H, Krone N, Cunliffe VT, van Eeden FJM (2020) Bidirectional crosstalk between HIF and Glucocorticoid signalling in zebrafish larvae. bioRxiv. https://doi.org/10.1101/748566

23. Baddela VS, Sharma A, Michaelis M, Vanselow J (2020) HIF1 driven transcriptional activity regulates steroidogenesis and proliferation of bovine granulosa cells. Sci Rep 10(1):3906. https:// doi.org/10.1038/s41598-020-60935-1

24. Jiang Y-F, Tsui K-H, Wang P-H, Lin C-W, Wang J-Y, Hsu M-C, Chen Y-C, Chiu C-H (2011) Hypoxia regulates cell proliferation and steroidogenesis through protein kinase A signaling in bovine corpus luteum. Animal Reprod Sci 129(3):152-161. https://doi. org/10.1016/j.anireprosci.2011.12.004

25. Yu RM, Chaturvedi G, Tong SK, Nusrin S, Giesy JP, Wu RS, Kong RY (2015) Evidence for microRNA-mediated regulation of steroidogenesis by hypoxia. Environ Sci Technol 49(2):11381147. https://doi.org/10.1021/es504676s

26. Kodama T, Shimizu N, Yoshikawa N, Makino Y, Ouchida R, Okamoto K, Hisada T, Nakamura H, Morimoto C, Tanaka H (2003) Role of the glucocorticoid receptor for regulation of hypoxiadependent gene expression. J Biol Chem 278(35):33384-33391. https://doi.org/10.1074/jbc.M302581200

27. Zhang C, Qiang Q, Jiang Y, Hu L, Ding X, Lu Y, Hu G (2015) Effects of hypoxia inducible factor-1alpha on apoptotic inhibition and glucocorticoid receptor downregulation by dexamethasone in 
AtT-20 cells. BMC Endocr Disord 15:24. https://doi.org/10.1186/ s12902-015-0017-2

28. Semenza GL (2019) Pharmacologic targeting of hypoxia-inducible factors. Annu Rev Pharmacol Toxicol 59:379-403. https://doi. org/10.1146/annurev-pharmtox-010818-021637

29. Franke K, Kalucka J, Mamlouk S, Singh RP, Muschter A, Weidemann A, Iyengar V, Jahn S, Wieczorek K, Geiger K, Muders M, Sykes AM, Poitz DM, Ripich T, Otto T, Bergmann S, Breier G, Baretton G, Fong GH, Greaves DR, Bornstein S, Chavakis T, Fandrey J, Gassmann M, Wielockx B (2013) HIF-1alpha is a protective factor in conditional PHD2-deficient mice suffering from severe HIF-2alpha-induced excessive erythropoiesis. Blood 121(8):1436-1445. https://doi.org/10.1182/blood-2012-08-44918 1

30. Lambert-Langlais S, Val P, Guyot S, Ragazzon B, Sahut-Barnola I, De Haze A, Lefrancois-Martinez AM, Martinez A (2009) A transgenic mouse line with specific Cre recombinase expression in the adrenal cortex. Mol Cell Endocrinol 300(1-2):197-204. https://doi.org/10.1016/j.mce.2008.10.045

31. Muzumdar MD, Tasic B, Miyamichi K, Li L, Luo L (2007) A global double-fluorescent Cre reporter mouse. Genesis 45(9):593605. https://doi.org/10.1002/dvg.20335

32. Mitroulis I, Chen LS, Singh RP, Kourtzelis I, Economopoulou M, Kajikawa T, Troullinaki M, Ziogas A, Ruppova K, Hosur K, Maekawa T, Wang B, Subramanian P, Tonn T, Verginis P, von Bonin M, Wobus M, Bornhauser M, Grinenko T, Di Scala M, Hidalgo A, Wielockx B, Hajishengallis G, Chavakis T (2017) Secreted protein Del-1 regulates myelopoiesis in the hematopoietic stem cell niche. J Clin Invest 127(10):3624-3639. https://doi. org/10.1172/jci92571

33. Peitzsch M, Dekkers T, Haase M, Sweep FC, Quack I, Antoch G, Siegert G, Lenders JW, Deinum J, Willenberg HS (2015) An LC-MS/MS method for steroid profiling during adrenal venous sampling for investigation of primary aldosteronism. J Steroid Biochem Mol Biol 145:75-84

34. Eisenhofer G, Goldstein DS, Stull R, Keiser HR, Sunderland T, Murphy DL, Kopin IJ (1986) Simultaneous liquid-chromatographic determination of 3,4-dihydroxyphenylglycol, catecholamines, and 3,4-dihydroxyphenylalanine in plasma, and their responses to inhibition of monoamine oxidase. Clin Chem 32(11):2030-2033

35. Klotzsche-von Ameln A, Muschter A, Mamlouk S, Kalucka J, Prade I, Franke K, Rezaei M, Poitz DM, Breier G, Wielockx B (2011) Inhibition of HIF prolyl hydroxylase-2 blocks tumor growth in mice through the antiproliferative activity of TGFbeta. Cancer Res 71(9):3306-3316. https://doi.org/10.1158/0008-5472. CAN-10-3838

36. Singh RP, Franke K, Kalucka J, Mamlouk S, Muschter A, Gembarska A, Grinenko T, Willam C, Naumann R, Anastassiadis K, Stewart AF, Bornstein S, Chavakis T, Breier G, Waskow C, Wielockx B (2013) HIF prolyl hydroxylase 2 (PHD2) is a critical regulator of hematopoietic stem cell maintenance during steady-state and stress. Blood 121(26):5158-5166. https://doi.org/10.1182/ blood-2012-12-471185

37. Wiesener MS, Turley H, Allen WE, Willam C, Eckardt KU, Talks KL, Wood SM, Gatter KC, Harris AL, Pugh CW, Ratcliffe PJ, Maxwell PH (1998) Induction of endothelial PAS domain protein- 1 by hypoxia: characterization and comparison with hypoxiainducible factor-1alpha. Blood 92(7):2260-2268

38. Bertout JA, Majmundar AJ, Gordan JD, Lam JC, Ditsworth D, Keith B, Brown EJ, Nathanson KL, Simon MC (2009) HIF2alpha inhibition promotes p53 pathway activity, tumor cell death, and radiation responses. Proc Natl Acad Sci U S A 106(34):1439114396. https://doi.org/10.1073/pnas.0907357106

39. Rankin EB, Biju MP, Liu Q, Unger TL, Rha J, Johnson RS, Simon MC, Keith B, Haase VH (2007) Hypoxia-inducible factor-2
(HIF-2) regulates hepatic erythropoietin in vivo. J Clin Invest 117(4):1068-1077

40. Busceti LC, Ferese R, Bucci D, Ryskalin L, Gambardella S, Madonna M, Nicoletti F, Fornai F (2019) Corticosterone upregulates gene and protein expression of catecholamine markers in organotypic brainstem cultures. Int J Mol Sci. https://doi. org/10.3390/ijms20122901

41. Nguyen P, Peltsch H, de Wit J, Crispo J, Ubriaco G, Eibl J, Tai TC (2009) Regulation of the phenylethanolamine N-methyltransferase gene in the adrenal gland of the spontaneous hypertensive rat. Neurosci Lett 461(3):280-284. https://doi.org/10.1016/j.neule t.2009.06.022

42. Ramasz B, Kruger A, Reinhardt J, Sinha A, Gerlach M, Gerbaulet A, Reinhardt S, Dahl A, Chavakis T, Wielockx B, Grinenko T (2019) Hematopoietic stem cell response to acute thrombocytopenia requires signaling through distinct receptor tyrosine kinases. Blood 134(13):1046-1058. https://doi.org/10.1182/blood.20190 00721

43. Zieseniss A (2014) Hypoxia and the modulation of the actin cytoskeleton-emerging interrelations. Hypoxia (Auckl) 2:11-21. https://doi.org/10.2147/HP.S53575

44. Sormendi S, Deygas M, Sinha A, Krüger A, Kourtzelis I, Le Lay G, Bernard M, Sáez PJ, Gerlach M, Franke K, Meneses A, Kräter M, Palladini A, Guck J, Coskun Ü, Chavakis T, Vargas P, Wielockx B (2020) HIF2 $\alpha$ is a direct regulator of neutrophil motility. bioRxiv. https://doi.org/10.1101/2020.06.05.137133

45. Wagegg M, Gaber T, Lohanatha FL, Hahne M, Strehl C, Fangradt M, Tran CL, Schönbeck K, Hoff P, Ode A, Perka C, Duda GN, Buttgereit F (2012) Hypoxia promotes osteogenesis but suppresses adipogenesis of human mesenchymal stromal cells in a hypoxia-inducible factor- 1 dependent manner. PLoS ONE 7(9):e46483. https://doi.org/10.1371/journal.pone.0046483

46. Thomas LW, Ashcroft M (2019) Exploring the molecular interface between hypoxia-inducible factor signalling and mitochondria. Cell Mol Life Sci 76(9):1759-1777. https://doi.org/10.1007/s0001 8-019-03039-y

47. Pignatti E, Leng S, Yuchi Y, Borges KS, Guagliardo NA, Shah MS, Ruiz-Babot G, Kariyawasam D, Taketo MM, Miao J, Barrett PQ, Carlone DL, Breault DT (2020) Beta-catenin causes adrenal hyperplasia by blocking zonal transdifferentiation. Cell Rep 31(3):107524. https://doi.org/10.1016/j.celrep.2020.107524

48. Brattsand R, Linden M (1996) Cytokine modulation by glucocorticoids: mechanisms and actions in cellular studies. Aliment Pharmacol Ther 10(Sup2):81-90. https://doi.org/10.104 6/j.1365-2036.1996.22164025.x

49. Wurzburger MI, Prelevic GM, Brkic SD, Vuckovic S, Pendic B (1986) Cushing's syndrome-transitory immune deficiency state? Postgrad Med J 62(729):657-659. https://doi.org/10.1136/ pgmj.62.729.657

50. Newell-Price J, Bertagna X, Grossman AB, Nieman LK (2006) Cushing's syndrome. Lancet 367(9522):1605-1617. https://doi. org/10.1016/S0140-6736(06)68699-6

51. Smith LK, Cidlowski JA (2010) Glucocorticoid-induced apoptosis of healthy and malignant lymphocytes. In: Neuroendocrinology Pathological Situations and Diseases. Progress in Brain Research. pp 1-30. doi:https://doi.org/10.1016/s0079-6123(10)82001-1

52. Lee Y, Yi HS, Kim HR, Joung KH, Kang YE, Lee JH, Kim KS, Kim HJ, Ku BJ, Shong M (2017) The eosinophil count tends to be negatively associated with levels of serum glucose in patients with adrenal cushing syndrome. Endocrinol Metab (Seoul) 32(3):353359. https://doi.org/10.3803/EnM.2017.32.3.353

53. Ronchetti S, Ricci E, Migliorati G, Gentili M, Riccardi C (2018) How glucocorticoids affect the neutrophil life. Int J Mol Sci. https ://doi.org/10.3390/ijms 19124090

54. Lai KP, Li JW, Tse AC, Chan TF, Wu RS (2016) Hypoxia alters steroidogenesis in female marine medaka through miRNAs 
regulation. Aquat Toxicol 172:1-8. https://doi.org/10.1016/j.aquat ox.2015.12.012

55. Yun Z, Maecker HL, Johnson RS, Giaccia AJ (2002) Inhibition of PPAR gamma 2 gene expression by the HIF-1-regulated gene DEC1/Stra13: a mechanism for regulation of adipogenesis by hypoxia. Dev Cell 2(3):331-341. https://doi.org/10.1016/s1534 -5807(02)00131-4

56. Fecher RA, Horwath MC, Friedrich D, Rupp J, Deepe GS Jr (2016) Inverse correlation between IL-10 and HIF-1alpha in macrophages infected with Histoplasma capsulatum. J Immunol 197(2):565-579. https://doi.org/10.4049/jimmunol.1600342

57. Azhar S, Dong D, Shen WJ, Hu Z, Kraemer FB (2020) The role of miRNAs in regulating adrenal and gonadal steroidogenesis. J Mol Endocrinol 64(1):R21-R43. https://doi.org/10.1530/JME-19-0105

58. Hu Z, Shen WJ, Kraemer FB, Azhar S (2017) Regulation of adrenal and ovarian steroidogenesis by miR-132. J Mol Endocrinol 59(3):269-283. https://doi.org/10.1530/JME-17-0011
59. Coutinho AE, Chapman KE (2011) The anti-inflammatory and immunosuppressive effects of glucocorticoids, recent developments and mechanistic insights. Mol Cell Endocrinol 335(1):213. https://doi.org/10.1016/j.mce.2010.04.005

60. Weiner ID (2013) Endocrine and hypertensive disorders of potassium regulation: primary aldosteronism. Semin Nephrol 33(3):265-276. https://doi.org/10.1016/j.semnephrol.2013.04.007

61. Saffar AS, Ashdown H, Gounni AS (2011) The molecular mechanisms of glucocorticoids-mediated neutrophil survival. Curr Drug Targets 12(4):556-562. https://doi.org/10.2174/138945011794751 555

Publisher's Note Springer Nature remains neutral with regard to jurisdictional claims in published maps and institutional affiliations. 